\title{
Variation and adaptation in limpograss (Hemarthria altissima)
}

\author{
P.W. WOODS, J.N. COUCHMAN and H.A. BARLOW \\ AgResearch, PO Box 194. Kaikohe
}

\begin{abstract}
Persistent and productive cultivars of limpograss (Hemarthria altissima (Poir.) Stapf et C.E. Hubb.) are required if the species is to be useful in Northland cattle systems. A study was undertaken to investigate plant morphological traits, adaptation and persistence of 8 accessions. A series of abandoned research sites was revisited to determine long-term persistence and adaptation. Trials were established at 4 new sites throughout the northern North Island to assess morphological variation and plant survival. There was considerable variation in morphological traits assessed and plant survival, allowing scope for future selection. Bigalta used in earlier research trials had largely failed to persist under normal pasture management practices. Future work should use the cultivar Floralta.
\end{abstract}

Keywords: adaptation, flowering, Hemarthria altissima, leaf, morphological variation, persistence, seed, stolon

\section{Introduction}

The potential of limpograss (Hemarthria altissima (Poir.) Stapf et C.E. Hubb.) as a special-purpose perennial summer forage or component of mixed pasture in Northland dairy and beef cattle systems has been demonstrated (Taylor et al. 1976; Rumball \& Lambert 198 I ; Davies \& Hunt 1983). Persistent and productive cultivars are now needed if the species is to succeed. Limpograss is most likely to flourish on sites with fertile moisture-retentive soils, low frost occurrence (limit about $-6^{\circ} \mathrm{C}$ ), supplemented by $200-300 \mathrm{~kg} \mathrm{~N} / \mathrm{ha}$ from November to March, and perhaps irrigation (Taylor et al. 1976; Davies \& Hunt 1983). Stands require vegetative establishment, and remain dormant through winter. Growth rates from January to March exceed $100 \mathrm{~kg}$ $\mathrm{DM} / \mathrm{ha} /$ day, with digestibility of $68-72 \%$ and protein content of 12-13\% (Rumball 1989).

Limpograss is a stoloniferous grass of the tribe Andropogoneae and family Poaceae. Many genotypes were collected from southern Africa during 1964 and 1971 by the USDA (Oakes 1973). Diploid, tetraploid and hexaploid forms exist (Quesenberry et al. 1982). Differences in leafiness, growth habit, internode length and anthocyanin content are readily apparent (Oakes 1973). Considerable development for cattle grazing occurred in Florida, leading to the release of the diploid cultivars Redalta (P1299993) and Greenalta (PI299994), and the tetraploid cultivars Bigalta (P1299995) and Floralta (PI364888). Significant variation exists between ploidy levels, diploids tolerating frost better, and tetraploids having superior in vitro digestibility (Quesenberry et al. 1982).

Bigalta was used extensively in comparisons with other grasses in Northland (Taylor et al. 1976; Rumball \& Lambert 198 1; Davies \& Hunt 1983) and in the Manawatu (Forde unpublished). Under favourable conditions limpograss production was comparable or better than other grasses and the species was considered to have lower weed potential. Paddock scale plantings of Bigalta occurred on four Northland and one South Auckland dairy farm, during the summers of 1981-84 (Taylor pers. comm.). With good establishment and management Bigalta performed well.

During the late 1970 s a subsample of accessions from the USDA collection representing a range of variation and elite germplasm was imported to New Zealand. Establishment, productivity, persistence and frost tolerance were evaluated by Davies \& Hunt (1989). At least $80 \%$ of stolon cuttings from coarse-stemmed lines established plants compared with only $40-50 \%$ of stolon cuttings from fine-stemmed lines. Initially, tetraploid cultivars performed better than other lines but subsequent yield was directly related to shoot tissue survival through winter, fine-stemmed lines being less damaged by frost than coarser tetraploids. Floralta was intermediate in its frost tolerance, yield and persistence. Three tetraploid lines were compared by Rumball (1989) in a plot trial under grazing, with and without nitrogen fertiliser. Bigalta and PI349753 were more susceptible to frost than Floralta. In vitro digestibility and crude protein contents were highest in Bigalta $(72.1 \%, 12.8 \%)$ with Floralta and PI349753 slightly less. Efficiency of response to applied nitrogen was greatest with Floralta, and slightly less with Bigalta.

Two further accessions from South Africa (1 1 and 12) were imported during 1992, and were included in the work reported here. This paper reports observations from visits to abandoned research sites, and field trial information on morphological variation and survival among limpograss lines available in New Zealand. 


\section{Materials and methods}

To assess persistence, abandoned trial sites where limpograss had been previously established in Northland were visited during September 1992. Historical reports of naturalised populations were investigated. A set of field trials was established during December 1993 to gain further information on the available range of accessions in New Zealand.

\section{Field trials}

Trials comparing 8 lines of limpograss (Table 1) were established at 4 sites in the northern North Island (Kaitaia, Dargaville, Hamilton and Te Puke). Two weeks prior to planting, sites were sprayed with Roundup at 6 1/ha. Plants were propagated from single node cuttings of each accession established under glasshouse conditions at Kaikohe during early spring 1993. Plants were transplanted on a $1.0 \mathrm{~m} \times 1.0 \mathrm{~m}$ grid, 10 plants per plot, in a randomised complete block design with 3 replicates, repeated at each of the four sites. At planting stolons were less than $100 \mathrm{~mm}$ in length. Young plants were watered for 2 weeks after transplanting. To allow full expression of morphological traits, plots were left ungrazed from December to April, but were grazed by dairy cows for the remainder of the year. Basal fertiliser was applied annually during December and nitrogen as urea applied to each plant at every site visit. Assessments were made during late autumn 1994 and again in late spring 1994. A single whole plant typical of the plot was removed for dissection, dry weight and morphological assessment. Basal stolons at the plant crown and aerial stolon branches were counted and measured. Ten samples from each plant were measured for mature stolon width, and mature leaf width and length.

\section{Statistical analysis}

Field trial data across environments were pooled, and measurements for all variates rank transformed (Conover \& Iman 1981) for analysis. Pooled site analyses taking into account all sources of variation, were performed using the balanced analysis of variance procedure of Genstat. Standard errors of differences (SED) were calculated from rank transformed data. Pooled means across environments were also calculated from raw data.

\section{Results and discussion}

\section{Abandoned trial site visits and naturalised populations}

Observations were made where large scale limpograss plantings of Bigalta had occurred 10-13 years ago (Taylor pers. comm.). Sites were: Omahuta Rd, Mangamuka; Te Karae Rd, Kohukohu; Pukey's Rd,
Kaitaia; and Pekerau Rd, Taipa. During the period of uncontrolled management, Bigalta had virtually disappeared from three of the four sites. A strong population was present at Kohukohu. The paddock was in a frostfree area on a Takahiwai clay, and was grazed by cattle and used for making hay each spring.

During 1982 and 1983, Davies \& Hunt (1989) established plots of 5 cultivars on a dairy farm near Kauri. PI364891 and PI364884 were the most prevalent. Floralta was present but at relatively low density. PI349753 and Bigalta had failed to persist. With favourable management the three surviving lines quickly dominated.

Naturalised limpograss was reported near Kaitaia (Edgar \& Shand 1987), but the population could not be relocated. A further wild population of a Hemarthria species of unknown origin was found at Haruru Falls, Paihia. Plants occupied a dry roadside site and had compact rhizome systems with erect culms, similar to diploid types of Hemarthria altissima reported elsewhere. Flowering occurred during January and February. Stolons were not present. Oakes (1973) noted that descriptions failed to include the term stolons or stoloniferous, but most accessions are strongly stoloniferous. Other local material may be found in the future, and this may provide useful comparative genetic material for selection programmes.

\section{Yield and survival in field trials}

Yield and persistence will affect the success of limpograss under farming conditions. P1349753, SA1, Bigalta and Floralta had the highest yields of both leaf and stolon material (Table 1). Stolons formed the largest component of harvested plant material. Small differences in the percentages of leaf and stolon material occurred among accessions. Percentage of dead material harvested was relatively minor. The number, width and length of stolons differed significantly among accessions (Table 2). PI364884 had many relatively fine short stolons, compared with accession 11 with relatively few coarse long stolons. SA1, Bigalta and Floralta had moderate numbers of coarse relatively short stolons which were reflected in the dry weight per $m$ of stolon. Some finestemmed accessions had poor dry weight per $\mathrm{m}$ of stolon which conforms with poor vegetative establishment recorded by Davies \& Hunt (1989). Total length of stolon per plant was least in the improved cultivars. Under grazing conditions it is unlikely stolons would achieve the lengths and sizes recorded in this trial. Nevertheless stolons will form a large and very significant component of plant material available for animal consumption. Despite this, tetraploids retain good feed quality, but it does decline with maturity (Schank et al. 1973). Accessions varied considerably in mature 
Table 1 Pooled environment rank transformed means and standard error of the difference, with pooled environment data means for total plant dry weight and botanical dissection components.

\begin{tabular}{|c|c|c|c|c|c|c|c|c|c|c|c|c|}
\hline \multirow[t]{2}{*}{$\begin{array}{l}\text { Limpograss } \\
\text { accession }\end{array}$} & \multirow{2}{*}{\multicolumn{2}{|c|}{$\begin{array}{c}\text { Total plant } \\
\text { dry weight } \\
\text { Rank q/plant }\end{array}$}} & \multirow{2}{*}{\multicolumn{2}{|c|}{$\begin{array}{l}\text { Leaf dry weight } \\
\text { per plant } \\
\text { Rank q/plant }\end{array}$}} & \multicolumn{2}{|c|}{$\begin{array}{l}\text { Stolon dry weight } \\
\text { per plant }\end{array}$} & \multicolumn{2}{|c|}{$\%$ Leaf } & \multicolumn{2}{|c|}{$\%$ Stolon } & \multicolumn{2}{|c|}{$\begin{array}{l}\% \text { Dead } \\
\text { material }\end{array}$} \\
\hline & & & & & $\mathrm{R}$ a n k & g/plant & Rank & $\%$ & Rank & $\%$ & Rank & $\%$ \\
\hline PI349753 & 66.5 & 487 & 66.7 & 101.2 & 66.5 & 369 & 59.4 & 20.2 & 35.3 & 76.3 & 55.7 & 3.6 \\
\hline PI364891 & 33.8 & 224 & 30.4 & 36.8 & 35.1 & 180 & 23.1 & 15.9 & 72.5 & 80.8 & 50.4 & 3.3 \\
\hline PI364884 & 37.1 & 254 & 38.3 & 50.6 & 36.5 & 195 & 53.5 & 19.9 & 42.9 & 76.9 & 46.2 & 3.2 \\
\hline SA1 & 62.9 & 462 & 62.9 & 91.3 & 62.6 & 353 & 54.5 & 19.7 & 40.4 & 76.9 & 50.0 & 3.4 \\
\hline Bigalta & 53.5 & 366 & 59.7 & 81.2 & 52.0 & 273 & 77.3 & 22.6 & 22.8 & 74.5 & 41.7 & 3.0 \\
\hline Floralta & 52.8 & 361 & 52.6 & 71.2 & 52.4 & 276 & 53.7 & 19.6 & 38.6 & 76.7 & 55.6 & 3.7 \\
\hline 11 & 43.8 & 324 & 41.2 & 58.9 & 44.7 & 258 & 33.9 & 17.7 & 66.9 & 79.4 & 45.7 & 3.0 \\
\hline 12 & 37.5 & 251 & 36.2 & 45.4 & 38.1 & 199 & 32.6 & 17.1 & 68.7 & 80.1 & 42.7 & 2.8 \\
\hline SED & 7.6 & & 7.1 & & 7.7 & & 8.6 & & 7.8 & & 11.2 & \\
\hline
\end{tabular}

Table 2 Pooled environment rank transformed means and standard error of the difference and pooled environment means of data for stolon characters of limpograss lines.

\begin{tabular}{|c|c|c|c|c|c|c|c|c|c|c|c|c|}
\hline \multirow[t]{2}{*}{$\begin{array}{l}\text { Limpograss } \\
\text { accession }\end{array}$} & \multicolumn{2}{|c|}{$\begin{array}{l}\text { Number of basal } \\
\text { stolons per plant }\end{array}$} & \multicolumn{2}{|c|}{$\begin{array}{l}\text { Number of aerial } \\
\text { stolons per plant }\end{array}$} & \multicolumn{2}{|c|}{$\begin{array}{l}\text { Mature stolon } \\
\text { width }\end{array}$} & \multicolumn{2}{|c|}{$\begin{array}{c}\text { Mature stolon } \\
\mathrm{g} / \mathrm{m}\end{array}$} & \multicolumn{2}{|c|}{$\begin{array}{l}\text { Length of longest } \\
\text { stolon }\end{array}$} & \multicolumn{2}{|c|}{$\begin{array}{l}\text { Total stolon } \\
\text { length per plant }\end{array}$} \\
\hline & Rank & No. & Rank & No. & Rank & $\mathrm{m} \mathrm{m}$ & Rank & $\mathrm{g} / \mathrm{m}$ & Rank & $\mathrm{m}$ & Rank & $\mathrm{m}$ \\
\hline PI349753 & 40.4 & 64 & 78.2 & 638 & 37.21 & 4.0 & 28.2 & 1.701 & 36.5 & 1.700 & 70.5 & 208 \\
\hline PI364891 & 34.4 & 55 & 49.6 & 269 & 24.08 & 3.2 & 22.0 & 1.553 & 65.3 & 2.083 & 48.7 & 119 \\
\hline PI364884 & 53.8 & 90 & 60.5 & 432 & 10.58 & 2.5 & 33.2 & 2.658 & 32.3 & 1.833 & 44.2 & 109 \\
\hline SA1 & 49.9 & 83 & 26.9 & 129 & 82.54 & 6.6 & 77.2 & 3.521 & 57.6 & 1.942 & 47.7 & 108 \\
\hline Bigalta & 46.2 & 76 & 34.9 & 158 & 85.71 & 6.8 & 77.1 & 3.455 & 40.2 & 1.725 & 36.9 & 79 \\
\hline Floralta & 46.5 & 74 & 43.3 & 216 & 86.79 & 5.4 & 66.0 & 2.942 & 32.2 & 1.633 & 44.0 & 96 \\
\hline 11 & 23.1 & 38 & 41.7 & 190 & 47.29 & 4.4 & 41.2 & 2.025 & 89.8 & 2.975 & 49.6 & 125 \\
\hline 12 & 28.1 & 46 & 46.4 & 233 & 33.79 & 3.8 & 38.4 & 2.005 & 34.1 & 1.708 & 45.1 & 107 \\
\hline SED & 5.6 & & 9.1 & & 5.43 & & 9.5 & & 7.5 & & 9.2 & \\
\hline
\end{tabular}

Table 3 Pooled environment rank transformed means, standard error of the difference, and pooled environment data means for the number of rooted stolon nodes, plant survival, mature leaf width and length, and flowering.

\begin{tabular}{|c|c|c|c|c|c|c|c|c|c|}
\hline \multirow[t]{2}{*}{$\begin{array}{l}\text { Limpograss } \\
\text { accession }\end{array}$} & \multicolumn{2}{|c|}{$\begin{array}{l}\text { Mature leaf } \\
\text { width }\end{array}$} & \multicolumn{2}{|c|}{$\begin{array}{l}\text { Mature leaf } \\
\text { length }\end{array}$} & \multicolumn{2}{|c|}{$\begin{array}{l}\text { Number of rooted } \\
\text { stolon nodes per plant }\end{array}$} & \multicolumn{2}{|c|}{$\begin{array}{l}\text { Surviving plants from } \\
\text { ten originals }\end{array}$} & \multirow{2}{*}{$\begin{array}{l}\text { Presence } \\
\text { or absence } \\
\text { of flowers }\end{array}$} \\
\hline & Rank & $\mathrm{mm}$ & Rank & $\mathrm{mm}$ & Rank & No./plant & Rank & No. & \\
\hline PI349753 & 39.7 & 6.1 & 37.3 & 17.7 & 61.8 & 782 & 23.2 & 4 & Present \\
\hline $\begin{array}{l}\text { Pi364891 } \\
\text { PI364884 }\end{array}$ & $\begin{array}{r}31.2 \\
9.8\end{array}$ & $\begin{array}{l}5.8 \\
4.8\end{array}$ & $\begin{array}{l}23.1 \\
18.6\end{array}$ & $\begin{array}{l}14.7 \\
13.9\end{array}$ & $\begin{array}{l}49.5 \\
50.0\end{array}$ & $\begin{array}{l}522 \\
542\end{array}$ & $\begin{array}{l}29.0 \\
29.4\end{array}$ & $\begin{array}{l}5 \\
5\end{array}$ & $\begin{array}{l}\text { Present } \\
\text { Present }\end{array}$ \\
\hline SA1 & 82.5 & 8.9 & 77.6 & 29.0 & 45.7 & 455 & 49.3 & 8 & Absent \\
\hline Bigalta & 86.3 & 9.1 & 81.0 & 28.9 & 39.7 & 329 & 44.3 & 7 & Absent \\
\hline Floralta & 57.9 & 6.8 & 65.4 & 24.3 & 53.6 & 569 & 51.6 & 8 & Rare, very late \\
\hline 11 & 38.8 & 6.1 & 52.7 & 20.3 & 37.0 & 334 & 13.4 & 3 & Few, late \\
\hline 12 & 41.9 & 6.2 & 32.3 & 16.6 & 47.7 & 471 & 36.7 & 6 & Many, early \\
\hline SED & 7.0 & & 4.9 & & 7.7 & & 5.8 & & \\
\hline
\end{tabular}

leaf width and length, improved cultivars having the widest and longest leaves (Table 3).

Seeding, long stolons and rooting from nodes, are mechanisms by which limpograss may spread and establish secondary plants. Advantages of such mechanisms should be considered against possible weed potential. Under grazing, Bigalta and Floralta form large plants with distinct crowns and minimal rooting from stolon nodes, so that there is limited scope for secondary plants to establish, unless stolons are dislodged from the parent plant and fragments root. These observations conflict with data presented for these cultivars in Table 3. PI349753 had considerable lateral and aerial branching (Table 2) with rooting from nodes (Table 3 ), thus enhancing establishment of secondary plants, most of which failed to survive winter. Floralta, SAI and 
Bigalta had the best short-term survival. Accession 11 had the poorest survival.

\section{Flowering and seeding}

The need for vegetative establishment is a major constraint to use of limpograss in New Zealand. Flowering and seed set were observed on some lines. Flowering time differed among lines, ranging from January to April. Flowers consisted of a small spikelike raceme, usually several per culm. Flowers were not observed on Bigalta or SAI, and only rarely on Floralta usually when plants were under environmental stress late in the growing season (June). Little or no flowering has advantages in terms of maintaining forage quality. Seed set under both field and greenhouse conditions is low (Quesenberry et al. 1978; Wilms et al. 1970). Seed is enclosed in a lignified hull. Small quantities harvested and sown locally have largely failed to produce plants. Quesenberry (pers. comm.) concluded that it was impractical to produce quantities necessary for commercial propagation via seed. Mature racemes often lie within the canopy and separation of seed from foliage would be difficult. Capacity to produce seed and the presence of naturalised wild populations as a potential source of pollen or seed contamination needs consideration in terms weed potential.

\section{Use}

Limpograss retains many of the benefits of both annual crops and subtropical grass components of pasture, but offers advantages in terms of perenniality and flexibility of use. Improved cultivars of limpograss may be used as components in mixed pasture, but are probably best suited to development as standing feed banks for in situ feeding of cattle during summer. It may take 24 months for sufficient feed to accumulate, but this is comparable to traditional summer crops. Limpograss would not require annual re-establishment, but compatible coolseason species are needed for winter production. Previous large-scale plantings used Bigalta, which although establishing and producing well, has generally failed to persist. Further work on Floralta is warranted as it appears better suited to New Zealand management conditions.

Feed conservation techniques may increase flexibility of forage use options. Farmers have expressed interest in using fine-stemmed limpograss lines for hay. Concerns about drying times necessary for coarsestemmed material could easily be overcome by conditioning treatments. Ensiling surplus feed may be a better option. Fine-stemmed material could be more lignified, and fleshy coarse-stemmed material might be associated with high starch reserves, as occurs in many temperate grasses. The use of silage additives during limpograss ensiling and their effect on feed quality, should be investigated.

Limpograss may also have potential as a forage crop under irrigation or for cowshed effluent disposal during summer. The species is adapted to high soil fertility and can tolerate wet soils and intermittent flooding during warm conditions (Woods et al. 1993).

\section{Conclusions}

Considerable variation exists among the few accessions present in New Zealand. There is scope for developing lines for specific forage and conservation purposes. Coarse-stemmed lines appear suited to producing a bulk of summer feed for cattle enterprises. Fine-stemmed material may have a role in forage conservation and sheep systems.

The cultivars Bigalta and Floralta arc unlikely to become weeds. Without controlled management Bigalta has generally failed to persist. Future research should focus on the use of Floralta. Failure to produce sufficient quantities of seed, necessitating vegetative establishment, will remain a constraint to use in New Zealand.

Results on morphological characteristics obtained in this study concurred with previous reports. Revisiting abandoned trial sites was invaluable in determining longterm persistence under field conditions. Such information could not be reliably obtained from short-term intensively managed trials.

Further research is required to determine the place of limpograss in farming systems and management necessary to optimise production. Limpograss overwintered at all sites sampled in the northern North Island and the species may be successful in regions other than Northland.

\section{ACKNOWLEDGEMENTS}

The Foundation for Research, Science and Technology for funding. Steve Matthews, Tangonge Rd, Pukepoto, Kaitaia; Steve McKenzie, Aoroa Rd, Aoroa, Dargaville; Kelvin and Steve Reynolds, Pah Rd, Te Puke; for the provision of trial sites. Fiona Clarkson and Roslyn McCabe, Dairying Research Corporation, Hamilton; for the provision of land and trial servicing. John Waller, AgResearch, Ruakura for statistical analysis. Peter Boyce, Mark Smith and Warren Dargaville for sampling and dissections.

\section{REFERENCES}

Conover, W.J.; Iman, R.L. 1981. Rank transformations as a bridge between parametric and non-parametric statistics. American statistician 35: 124-133. 
Davies, L.J.; Hunt, B.J. 1983. Growth of tropical grass introductions in mixed swards with ryegrass and clover under mowing. New Zealand journal of agricultural research 26: 415-422.

Davies, L.J.; Hunt, B.J. 1989. Evaluation of five introductions of the subtropical grass Hemarthria altissima at a frost-prone site in Northland. New Zealand journal of agricultural research 32: 469476.

Edgar, E.; Shand, J.E. 1987. Checklist of Panicoid grasses naturalised in New Zealand; with a key to native and naturalised genera and species. New Zealandjournal of botany 25: 343-3.53.

Oakes, A.J. 1973. Hemarthria collection from South Africa. Turrialba 23: 37-40.

Quesenberry, K.H.; Oakes, A.J.; Jessop, D.S. 1982. Cytological and geographical characterizations of Hemarthria. Euphytica 31: 409-4 16.

Quesenberry, K.H. et al. 1978. Redalta, Greenalta and Bigalta limpograss, Hemarthria altissima, promising forages for Florida. Florida Agriculture Experiment Station Bulletin 802: 1-18.

Rumball, P.J. 1989. Performances of three lines of limpograss (Hemarthria aftissima) in mixed pasture.
New Zealand journal of agricultural research 32: 151-155.

Rumball, P.J.; Lambert, J.P. 1981. Plant introduction trials. Performance of some subtropical grasses in Northland. New Zealand journal of experimental agriculture 9: 79-83.

Schank, S.C.; Klock, M.A.; Moore, J.E. 1973. Laboratory evaluation of quality in limpograss: II. Genetic variation among Hemarthrias in in vitro digestion and stem morphology. Agronomyjournal 65: 256-258.

Taylor, A.O.; Rowley, J.A.; Hunt, B.J. 1976. Potential of new summer grasses in Northland. II. A further range. of grasses. New Zealand journal of agricultural research 19: 477-48 1.

Wilms, H.J.; Carmichael, J.W.; Schank, S.C. 1970. Cytological and morphological investigations on the grass Hemarthria altissima (Poir) Stapf \& C.E. Hubb. Crop science IO: 309-3 12.

Woods, P.W.; Couchman, J.N.; Taylor, A.O. 1993. Flood tolerant pastures for dairying in Northland. Proceedings of the XVII International Grassland Congress 17: 1522-l 523. 